\title{
INCORPORATING META-COGNITIVE INSTRUCTION IN READING COMPREHENSION INTO PHILOLOGY TRAINING
}

Kush J. C.

Professor

ORCID ID 0000-0001-9614-6351

Ukraine Fulbright Scholar

Duquesne University 600 Forbes Avenue Pittsburgh PA 15282

United States of America

kush@duq.edu

This article describes a novel pedagogical method for improving the L2 reading comprehension of philology students. Often, students who encounter comprehension difficulties when reading material in a second language are instructed to re-read the passage a second or a third time with the hopes that the repetition will cause the material to be better understood. All too often, this goal is unrealized and explicit, direct instruction strategies have consistently been found superior than none-intentional, repetitive reading. One particular strategy called $3 \mathrm{Hs}$ - Here, Hidden, and in my Head, is a strategy designed to identify question-answer relationships. Here refers to information that is text explicit. Hidden requires students to make inferences based on text implicit information and Head requires students to access and utilize their own prior knowledge to answer a text-based question. Using a student-centered learning strategy, the jigsaw method, students were introduced to the $3 \mathrm{H}$ method and were encouraged to integrate the approach into their philology studies.

Keywords: reading comprehension, student-centered learning, jigsaw method, Here/Hidden/Head.

\section{Introduction}

University philology students are required to read a large volume of academic texts in in foreign languages. Unfortunately, however, many of these students begin their university coursework underprepared for the reading demands necessary for academic success [1]. When errors are encountered, they often include an inability to successfully distinguish important information from insignificant or trivial details [2]. Additionally, they often possess poorly developed reading strategies [3] and they may utilize ineffective and inefficient strategies [4]. Further, the role of language structure in second language reading comprehension has been identified in a number of studies $[5,6,7]$, and may compound comprehension difficulties.

Numerous investigators have examined the reading process in philology students. Clearly, reading is a necessary tool for second language acquisition, not only as a source of information, but also as a means of expanding one's knowledge of the language and its related aspects of culture and history. Reading acquisition is a complex process involving a combination of cognitive, metacognitive, linguistic and sociolinguistic elements. Within philology coursework, reading instruction is often geared towards teaching foreign culture idioms, with minimal reference to the communicative nature of the reading process. Relatedly, Laufer [8] posited that there is a lexical threshold for reading comprehension consisting of approximately 5,000 words, and that even highly skilled readers in their native language cannot read well in L2 if their vocabulary is below this threshold.

Prior research has demonstrated that explicit instruction of reading strategies leads to improved reading comprehension $[9,10,11]$. Strategic awareness of the comprehension

(C) Куш Дж. С., 2019 
process is a critically important aspect of skilled reading [12, 13, 14]. This awareness represents a component of metacognition, which "entails knowledge of strategies for processing texts, the ability to monitor comprehension, and the ability to adjust strategies as needed" [15, p. 240]. Sheorey \& Mokhtari [14], have posited that the combination of conscious awareness of the strategic reading processes and the actual use of reading strategies distinguishes skilled from less-skilled readers.

The scientific novelty of the study

In particular, studies examining L1 and L2 environments have shown that successful reading strategy use is dependent on whether the strategy is employed metacognitively [16, 17]. Unsuccessful students not only lack this strategic awareness and monitoring of their own comprehension process [18] but must be assisted in the acquisition and use of successful reading strategies [19]. It is clearly, important therefore for non-native readers to be aware of the metacognitive strategies proficient reading requires so that they are better able to become "constructively responsive" readers [13].

The specific topic of the study

Explicit, direct instruction of reading comprehension strategies. has demonstrated positive effects on improving reading comprehension $[9,10,20,21]$. One explicit reading comprehension strategy with particular promise for philology students is the Here, Hidden, Head $(\mathrm{HHH}$ or $3 \mathrm{H})$ method. The technique incorporates both mnemonic and metacognitive features [22] and the $3 \mathrm{H}$ mnemonic - Here, Hidden, and in my Head-provides a simple way to remember useful information about reading, specifically, where the answers to questions can be found.

The $3 \mathrm{H}$ method is a strategy to identify question-answer relationships and is intended to guide the learner to where the information necessary for answering the question can be located. The question can be explicitly stated in the text (Here on the page); implied in the text and integrated with the student's background knowledge (Hidden) or not stated directly in the text and solely based on the student's background knowledge [23]. This technique does not simply direct students to look back in the text or read in a random way if they are unable to respond to the question after reading the passage. Instead, the $3 \mathrm{H}$ strategy is designed to help them to read strategically by explicitly teaching students how to navigate through material to seek the material they need to correctly answer the question [10]. Specifically, the $3 \mathrm{H}$ strategy has two primary features: (a) it activates students' background knowledge before comprehension questions are asked; (b) it provides explicit information about how to select appropriate sources of information and answer comprehension questions.

\section{Research method}

Intermediate philology students at Sumy State University were introduced to the $3 \mathrm{H}$ method in two phases. In the initial phase, students were introduced to the instructional strategy and were given examples to practice with. The $3 \mathrm{H}$ strategy was presented as a strategy which is useful because it reminds students where the answers to questions are found. All instruction occurred in English.

\section{Research materials}

Using a framework adopted from Graham [24], Here questions were identified as textexplicit as they could be identified completely by using information contained within the passage. As one example, students were given the following American nursery rhyme:

Jack and Jill went up a hill to fetch a pail of water.

Jack fell down and broke his crown.

And Jill came tumbling after.

Subsequently, students were asked the following question, "Who was going up the hill?", with the answer (Jack and Jill) being identified as a Here question as the names were directly contained within the passage. 
Next, Hidden questions were identified as text-implicit as only part of the response is located in the passage. Information to answer Hidden questions was described as being found in two or more sentences in a passage or, alternately, partly in the passage and partly in what the student already knows. The mnemonic Hidden was used to underline the extra effort that is often necessary to join together information to form an answer for this type of question. For this example, students were given the following passage:

Katharine was feeling very content. She was inside her house with a cup of hot chocolate and her cats snuggling near her feet. It was cold and snowing outside but the warmth of the fireplace helped made her forget about the errands she needed to do. "The errands can wait until tomorrow" she said to Isadore the tabby, who seemed to understand what she was saying and began to purr even louder.

The subsequent, example Hidden question was, "What season was it?", with the correct answer being winter. Students jokingly pointed out however that in Ukraine, snowing could also occur in the Fall or Spring, so those needed to be counted as correct answers as well. The facts that they recognized that the question could not be answered merely by reading and re-reading the passage, but required them to combine information from the text (snowing) with their personal knowledge (snow occurs in the winter) AND that they could humorously identify exceptions to the rule, clearly pointed out that they understood the strategy.

Finally, Head questions were defined as script-implicit and occurred when answers could only be given by using their knowledge base. No explicit or implicit information was available in the text to answer this type of question and they were required to use what they already know about the topic or offer their own opinion in response to the question. Examples of script implicit questions included "What do you think is going to happen next?" or "What did you like best about the story?"

In the next, phase of training students practiced what they learned by generating their own passages and questions and sharing them with the class. Instructional emphasis was on practice and reinforcing accurate comprehension performance and strategy use. Students were reminded that if there is no information to answer the question in the passage, the answer must be in their Heads. Relatedly, if the answer or part of the answer is found in the passage then the question is either Here or Hidden. In these instances, underlining information was presented as an effective way of ensuring that the passage had been scanned appropriately [25].

In the final phase of instruction, students completed a collaborative, student-centered activity designed to deepen their philology knowledge. Specifically, using a jigsaw method, students were divided into three groups and asked to identify 5 to 10 Ukrainian words that corresponded to Here, Hidden and Head. The jigsaw method is a collaborative technique based on Vygotskian theory that requires learners to first develop information in small groups and subsequently work to incorporate this information with the knowledge generated from the other groups. The term Jigsaw refers to a jigsaw puzzle, where the final image of the puzzle is constructed from many separate pieces fitting together. In the academic setting, the overarching task is completed when members of the team offer unique, jigsaw-cut efforts to the group.

Results of the research

This $21^{\text {st }}$ century skill is much like what Apple employees demonstrate in developing products like an iPhone. That is, specific component teams work initially on a separate design element of the product, (e.g., camera, battery, antenna) and subsequent meet to integrate the information into a final product, within pre-specified constraints (e.g., weight cannot be more than $10 \%$ greater than the previous model; cost cannot be more than $5 \%$ greater than the previous model). As a result, a newly designed battery, for example, that keeps a charge for $40 \%$ longer than the previous model, may have to be redesigned if it's weight, when added to the increased weight of the camera and the GPS system, produces a total phone that is too heavy.

In the present example, each of the three groups initially identified groups of Ukrainian words that translated into the English, Here, Hidden, Head. Subsequently each team reported 
back to the other groups attempting to find a mnemonic common ground. Initially, two groups identified common terms which necessitated the third group to re-discuss and revise their list. After a brief discussion the class identified the Ukrainian $3 \mathrm{H}$ equivalent: the $3 \mathrm{~T}$ method:

$$
\begin{array}{ll}
\text { 3-'H' } & \text { 3'Т' } \\
\text { Here } & \text { Тут } \\
\text { Hidden } & \text { Таємниця } \\
\text { Head } & \text { Тлумачення }
\end{array}
$$

\section{Conclusions}

Clearly the instructional goals had been met. Not only, will the students be able to use the metacognitive strategy to facilitate their future reading comprehension, but the crosscultural linguistic connection suggests that its' effectiveness will only be enhanced. It was further heartening to hear one of the students suggest that the process could probably be replicated for other languages such as German, and French. Additionally, students benefitted from the real-world, jigsaw strategy which helped to develop skills for working effectively in teams by emphasizing cooperation and shared responsibility within groups. The success of each group depended on the participation of each individual in completing their task. Jigsaw activities have been shown to improve team and class dynamics by helping to build trust, creating a space for openness and for respectful disagreement, and for taking emotional risks, important $21^{\text {st }}$ century skills.

\section{ВКЛЮЧЕННЯ МЕТАКОГНІТИВНОГО НАВЧАННЯ ЧИТАННЯ ДО ПІДГОТОВКИ ФІЛОЛОГІВ}

Куші Дж. С.

Професор

ORCID ID 0000-0001-9614-6351

Учений за програмою Фулбрайт в Україна

Університет Дюкейн, 600 Форбс Авеню, Пітсбург РА 15282

Сполучені Штаті Америки

kush@duq.edu

У статті описується новий педагогічний метод підвищення рівня розуміння прочитаного студентами-філологами, які вивчають іноземні мови.

Студенти філологічного факультету зобов'язані читати великий обсяг навчальних текстів на іноземних мовах. На жаль, багато хто з изих студентів починають свою університетську курсову роботу недостатньо підготовленими до вимог читання, необхідних для академічного успіху. Помилки, допущені студентами, демонструють проблематичність виокремлення важливої інформацію в прочесі читання. Недостатній рівень володіння стратегіями читання, а токож застосування неефективних стратегій, значно знижують якість читання. В той же час варто пім'ятати, про важливу роль мовної структури підчас сприйняття інформаџії протягом читання на іноземній мові, щзо може ускладнити розуміння прочитаного. Оволодіння читанням являє собою складний прочес, щзо включає поєднання когнітивних, метакогнітивних, лінгвістичних $i$ сочіолінгвістичних елементів. В рамках курсу філології навчання читанню часто орієнтоване на навчання ідіомам іноземної культури з мінімальним посиланням на комунікативний характер прочесу читання.

Досить часто, студенти, які стикаються з труднощами розуміння підчас читання матеріалів на іноземній мові, проінструктовані перечитувати уривок другий або третій раз сподіваючись, що повторення сприятиме кращому розумінню матеріалу. Дуже часто ия мета виявлясться нереалізованою, і явні, прямі стратегіі навчання виявляються набагато більш ефективними, ніж не навмисне читання 
одного і того ж матеріалу декілька разів. Одна конкретна стратегія під назвою 3 Hs (Here, Hidden, and in my Неаd) - тут, прихований, в моїи голові, - це стратегія, призначена для виявлення відносин "питання-відповідь". Here (тут) відноситься до інформації, яка є явним текстом. Hidden (прихований) вимагає від студентів робити висновки на основі тексту та неявної інформації. In my Неаd (в моїй голові) вимагає від студентів отримати доступ і використовувати свої власні попередні знання, щзоб відповісти на текстове питання.

Ключові слова: розуміння прочитаного, навчання, орієнтоване на учнів, метод головоломки, стратегія тут/прихований/у моїй голові.

\section{REFERENCES}

1. Dreyer, C. \& Nel, C. Teaching reading strategies and reading comprehension within a technology-enhanced learning environment. System, 31, 2003, 349-365 pp.

2. Benson, M. J. University ESL reading: A content analysis" English for Specific Purposes, 10, 1991, 75-88, pp.

3. Dreyer, C. Improving students' reading comprehension by means of strategy instruction. Journal for Language Teaching, 31, 1998, 18-29 pp.

4. Wood, E., Motz, M. \& Willoughby, T. Examining students' retrospective memories of strategy development. Journal of Educational Psychology, 90, 1998, 698-704 pp.

5. Alderson, J. C. Relationship between grammar and reading in an English for academic purposes test battery. In Douglas, D., and C. Chapelle, C. (Eds). A new decade of language testing research. 1993, 203-214 pp, Alexandria, VA: TESOL.

6. Alderson, J. C. Assessing reading. 2000, New York: Cambridge University Press.

7. Swaffar, J., Arens, K., \& Byrnes, H. Reading for meaning: An integrated approach to language learning. 1991, Englewood Cliffs, NJ: Prentice Hall.

8. Laufer, B. The concept of 'synforms' (similar lexical forms). Vocabulary Acquisition : Language and Education. 2 (2). 1998, 113-132 pp.

9. Casteel, C.P., Isom, B.A., \& Jordan, K.F. Creating confident and competent readers: Transactional strategies instruction. Intervention in School and Clinic, 36 (2),2000, 67-74 pp.

10. Eilers, L.H. \& Pinkley C. Metacognitive strategies help students to comprehend all text. Reading Improvement, 43 (1), 2006, 13-29 pp.

11. Pope, T. Getting serious (and practical) about helping struggling readers succeed. The Virginia English Bulletin, 57 (2), 2007, 59-63 pp.

12. Dhieb-Henia, N. Evaluating the effectiveness of metacognitive strategy training for reading research articles in an ESP context. English for Specific Purposes, 22, 2003, 387 417 pp.

13. Pressley, M., \& Afflerbach, P. Verbal protocols of reading: The nature of constructively responsive reading. 1995, Hillsdale, NJ, US: Lawrence Erlbaum Associates, Inc.

14. Sheorey, R., \& Mokhtari, K. Differences in the metacognitive awareness of reading strategies among native and non-native readers. System, 29, 2001, 431-449 pp.

15. Auerbach, E. \& Paxton, D. "It's not the English thing": Bringing reading research into the ESL classroom. TESOL Quarterly, 31, 1997, 237-261 pp.

16. Carrell, P., Pharis, B., \& Liberto, J. Metacognitive strategy training for ESL reading. TESOL Quarterly 23, 1989, 647-678 pp.

17. Jiménez García, R. T., García, G. E., \& Pearson, P. D. The reading strategies of bilingual Latina/o students who are successful English readers: Opportunities and obstacles. Reading Research Quarterly, 31, 1996, 90-112 pp.

18. García G.E., Jiménez, R. T., \& Pearson, P. D. Metacognition, childhood bilingualism, and reading. In D. Hacker, J. Dunlowsky \& A. Graesser (eds.), Metacognition in Educational Theory and Practice, 1998, 200-248 pp. Mahwah, NJ: Lawrence Erlbaum.

19. Mokhtari, K. \& Reichard, C. Investigating the strategic reading process of first and second language readers in two different cultural contexts. System 32, 2004, 379-394 pp. 
20. Boulware-Gooden, R., Carreker, S., Thornhill, A., \& Joshi, R. Instruction of metacognitive strategies enhances reading comprehension and vocabulary Achievement of third-grade students. Reading Teacher, 61(1), 2007, 70-77 pp.

21. Brown, R., Pressley, M., Van Meter, P., Schuder, T. A quasi-experimental validation of transactional strategies instruction with low-achieving second grade readers. Journal of Educational Psychology, 88, 1996, 18-37 pp.

22. Wong, B., Graham, L., Hoskyn, M., \& Berman, J. The ABCs of learning disabilities (2nd ed.). 2008, USA: Elsevier Inc.

23. Westwood, P. Reading and learning difficulties: Approaches to teaching and assessment. 2001, Australia: ACER Press.

24. Graham, L. The 3H strategy: Improving poor readers' comprehension of content area materials. Paper and workshop presented at the 19th National Conference of the Australian Association of Special Education, 1995, Darwin, NT.

25. Reutzel, D. R. \& Hollingworth, P. M. Highlighting the key vocabulary: A generativereciprocal procedure for teaching selected inference types. Reading Research Quarterly, 23(3), 1988, 358-378 pp.

Received: 20 May, 2019 